\title{
TECHNICAL ANALYSIS OF 12TH WORLD UNIVERSITIES WRESTLING CHAMPIONSHIP GRECO-ROMAN STYLE COMPETITION
}

\author{
Aydogan Soyguden ${ }^{1}$, Osman Imamoglu ${ }^{2}$ \\ Erciyes University ${ }^{l}$, Kayseri, Turkey \\ Ondokuz Mayls University', Samsun, Turkey
}

\begin{abstract}
Background. The purpose of this study was to carry out technical analysis of the 12th World Universities Wrestling Championships Greco-Roman style competition.

Methods. There were 70 participants from 18 countries participating in Corum, Turkey. The observation form was prepared before the competitions and recorded by two researchers; technical analysis of the recordings was carried out. During the competitions, the scores obtained, warnings, winning types, successful techniques were recorded in the technical analysis form. In statistical analysis, the percentage distributions for each parameter and match percentage rates were calculated. Statistical analysis was performed by One Way ANOVA and LSD analysis of variance in group comparisons.

Results. In the championships all the wrestlers applied 341 technics and collected 535 points. The Light weight groups applied 157 technics and collected 245 points in the 36 matches. The most number of points were collected and made in the light weight group. The heavyweight groups applied 63 technics and collected 116 points in the 19 matches. The least number of points were collected and made in the heavyweight groups. There was a significant difference between the technical and score points according to weight groups $(p<.05$ and $p<.001)$. The highest number of victories was taken (won by score) in the heavyweight group (83\%); the highest number of victories was taken (won by technical pin) in the lightweight group (21\%). The highest score was made with passive punishment point in lightweight group (28\%), middleweight group (38\%) and heavyweight group (33\%). The highest scores in the second row were obtained from the techniques of snap down spin behind with $(16 \%)$ at light weight, high dive takedown at $16.5 \%$ in middle weight, and move out of the mat and high dive takedown score at $22 \%$ in heavyweight groups. The ratio for one competition (ROC) was received by the number of technical 4.01 and 6.67 points.

Conclusion. As a result, the most effective technique in Greco-Roman style given by the referee was passive punishment point in all weight groups. In this case, the wrestlers need to be more active in the standing position around the zone area. In particular, it is suggested to fight tempo wrestling with their arms and chest by fighting against each other and struggle in the standing position.
\end{abstract}

Keywords: World Universities Wrestling, Greco-Roman style, competition analysis.

\section{INTRODUCTION}

A ccomplishment in wrestling can be achieved by the transformation of some criteria to high performance that are physical and physiological power, technical ability, mentality tactics, experience and motivation.
Ability is so important and success is achieved by combining ability with mentality and force.

The countries have to protect and pay attention to wrestlers that have these characteristics. If coaches know the effective techniques and systems, they 
can train their wrestlers better. Besides the physical and anthropometric characteristics, number and ratio of applied techniques in the competitions are important, too (Atan \& Imamoglu, 2005; Kolukisa, Imamoglu, Ziyagil, \& Kishali 2004a; Imamoglu, Atan, Kolukısa, Kaldırımcı, \& Kishali, 2004; Kolukisa, Ziyagil, Imamoglu, \& Kishali, 2004b).

Analysing the tendency of the development of wrestling in recent years, most of experts agree that for the development of wrestling, including it as the element of the program of the Olympic Games, it is necessary to make effort for the increase in effectiveness of wrestling duels at preservation of high intensity of fight throughout the whole fight (Sandberg \& Bell, 2007; Vardar, Tezel, \& Ozturk, 2007).

Ortega, Cardenas, Sainz De Baranda, and Palao (2006) contributed to the development and acquisition of information to improve the technical analysis of the competition. There are many indicators available for statistical analysis of sports performance. The estimates informed of the changes of the performances of the coaches and the athletes.

Mirvic, Kazazovic, and Aleksandrovic (2011) reported that after the events, feedback provided effective results in the use of positive transformations to improve performance of athletes. Mirvic et al. (2011) explained that this information gathered after the competition is open to discussing that objectively, validly and consistently, and developing new possibilities by analysing and evaluating the basic items of coaches and athletes.

The analysis of competition functions has become an urgent situation in modern developed wrestling. Furthermore, the maintenance of individual problems in training has always been an important study direction for researchers (Tropin, 2013; Ryan \& Sampson, 2006).

Mizerski (1972) found that after the preparation period, sports events are a very important test area for athletes and coaches. At the end of the any training process the achievements are evaluated according to the results of the sports competition

This study's objective was to analyse GrecoRoman wrestling technique during a 2016 12th World Universities Wrestling Championship. The specific aims were to: (1) calculate tournament successful technique rates in Greco-Roman wrestlers; (2) characterize the general technique of Greco-Roman tournament; and (3) compare the past tournament techniques to new Greco-Roman tournament techniques.

\section{LITERATURE REVIEW}

\section{International Wrestling Rules}

Types of victories: A bout may be won:

(By "fall"), (by injury, withdrawal, default, disqualification of the opponent), (by technical superiority), (by points, winning by 1 point more at minimum after addition of the two periods)

In case of tie by points, the winner will be declared by successively considering: (The highest value of holds), (The least amount of cautions), (The last technical point(s) scored) (UWW, 2017).

A match ends by technical superiority ( 8 points difference in Greco Roman wrestling and 10 points difference in Freestyle wrestling) (UWW, 2017).

Grand Amplitude Throw: Any action or hold by a wrestler in the standing position that causes his opponent to lose all contact with the ground, controls him, makes him describe a broadly sweeping curve in the air, and brings him to the ground in a direct and immediate danger position shall be considered a "Grand Amplitude" throw.

In the "parterre" position, any complete lift from the ground executed by the attacking wrestler, whether the attacked wrestler lands in neutral position (4 points) or in a danger position ( 5 points), is also considered a grand amplitude throw (UWW, 2017).

Clarification for stepping out in standing wrestling for both styles:

- When the attacking wrestler is the first to step into the protection area in the commission of a hold, the following may occur:

- If the wrestler completes the hold successfully in a continuous action, he shall be awarded the requisite points $1,2,4$ or 5 points.

- If the wrestler is unable to complete the hold successfully, after stopping the action the referee shall award his opponent 1 point.

- If the wrestler lifts and controls his opponent and he is unable to complete the hold in a continuous action, the referee shall stop the bout but not award his opponent 1 point (UWW, 2017).

\section{Values assigned to the Actions and Holds}

\section{1 point}

- To the wrestler whose opponent goes in the protection zone with one entire foot (in standing position) without executing a hold. Clarification for stepping out in standing wrestling for both styles: 
- When the attacking wrestler is the first to step into the protection area in the commission of a hold, the following may occur:

- If the wrestler completes the hold successfully in a continuous action, he shall be awarded the requisite points $-1,2,4$ or 5 points.

- If the wrestler is unable to complete the hold successfully, after stopping the action the referee shall award his opponent 1 point.

- If the wrestler lifts and controls his opponent and he is unable to complete the hold in a continuous action, the referee shall stop the bout but not award his opponent 1 point.

NB: When a wrestler deliberately pushes his opponent into the protection area with no meaningful action, he shall no longer be awarded 1 point. If he does it second time he will be penalized caution (0) and 2 points to opponent.

- All the stops of bout by injury without bleeding or any visible injury are penalized by 1 point to the opponent.

- To the wrestler whose opponent requested a challenge if initial decision is confirmed.

- To the opponent of a wrestler designated as passive who fails to score points during a 30 second activity period in Freestyle wrestling.

- Reversal (counter attack by dominated wrestler in parterre position and passing behind)

\section{2 points}

- To the wrestler who overcomes and then controls his opponent by passing behind (three points of contact: two arms and one knee or two knees and one arm or head).

- To the wrestler who applies a correct hold while standing on the mat or in the "parterre" position with three points of contact but who does not secure control by passing behind.

- To the wrestler who executes a hold that places his opponent's back at an angle of less than 90 degrees, including when his opponent is on one or two outstretched arms.

- To the wrestler who is prevented from completing a hold because his opponent is maintaining an irregular hold, but whom finally succeeds in completing the hold.

- To the attacking wrestler whose opponent flees the hold, the mat, refuses to start, commits illegal actions or acts of brutality.

- To the attacking wrestler whose opponent rolls onto his shoulders.
- To the attacking wrestler whose opponent flees the hold out-of-bounds and lands in a position of danger?

- To the attacking wrestler whose opponent commits an illegal hold that hinders the execution of an engaged hold or a fall

- To the wrestler who blocks his opponent in the execution of a hold from the standing position, in a position of danger.

- To the wrestler whose opponent, either top or bottom wrestler, refuses correct "parterre" position, in a position of danger

\section{4 points}

- To the wrestler performing a hold in a standing position, which brings his opponent into a danger position by direct projection over short amplitude.

- For any hold executed by raising a wrestler from the ground, over short amplitude, even if one or both of the attacking wrestler's knees are on the ground.

- To the wrestler who executes grand amplitude hold which does not place the opponent in a direct and immediate danger position.

\section{5 points}

- All grand amplitude throws executed in a standing position which brings the defending wrestler to a direct and immediate danger position.

- The hold executed by a wrestler in the "parterre" position who completely lifts his opponent off the ground with the execution of a high amplitude throw which projects the opponent into a direct and immediate danger position (UWW, 2017).

Procedure for enforcement of penalties for inactivity in Greco-Roman wrestling: Active Wrestling is defined by seeking contact with the opponent, hooking each other and trying to set up an attack. Both wrestlers are always encouraged to perform Active Wrestling.

If only one wrestler is performing Active Wrestling, he will be rewarded. In such cases, his opponent who is blocking and preventing Active Wrestling will be determined as passive and the appropriate passivity procedure takes place.

Ordered parterre for passivity is cancelled, and the following procedure will be enforced:

- First time issue a verbal warning to the passive wrestler by using UWW vocabulary without stopping the bout. No need to put a "V" on the score sheet 
- Second time (P) same wrestler is passive, referee will give 1st passivity warning, again without stopping the bout

- Third time (P) when the same wrestler is passive, referee shall give 2nd passivity warning and 1 technical point to his opponent, again without stopping the bout.

- Every further two passivity will result in 1 technical point to the opponent, all without stopping the bout (UWW, 2017).

Passivity Zone (Orange zone): The passivity zone that is orange coloured is provided for the purpose of detecting the passive wrestler; it is also intended to help eliminate systematic wrestling on the edge of the mat and any departures from the wrestling area.

Any hold or action begun on the central wrestling area and ending within that zone are valid including position of danger, counterattack and fall (UWW, 2017).

\section{METHODS}

The 12th World Universities wrestling competitions were held in Corum / Turkey on 25-30 October 2016 with 70 participants from 18 countries (Hitit University, 2016). The competition technical analysis study covers a total of 85 competitions made in 8 kilo groups.

Researchers developed observation form and collected all the techniques made by wrestlers. In the championships 85 matches were recorded by 2 researchers on the observation form. All the data collected after the tournaments were processes using the SPSS statistical analysis for distribution of frequencies.

The developed observation form included the types of winning matches, points earned techniques, and techniques made on the ground and in the stands position, objections and received warnings.

World universities Greco-Roman competitions were held in 3 minutes of 2 periods. In the competitions, kilograms were grouped and distributed as 59, 66 and 71 kilos light weight, 75, 80 and 85 kilos medium weight and 98 weight and 130 kilos weight as heavy weight.

Analysis: The statistical analysis of the percentile distribution for each parameter and the percentages per game were performed. Statistical analysis of the data was performed using the SPSS 21.0 program. Statistical analysis was performed by One Way ANOVA (Post Hoc Multiple Comparisons) and LSD (Least Significant Difference) analysis of variance in group comparisons. Significance level was taken as $\alpha=.05$.

\section{RESULTS}

Table 1 presents the weights listed in groups as light, medium and heavyweight.

Table 1. Distribution of kilo groups

\begin{tabular}{|l|l|}
\hline \multicolumn{1}{|c|}{ Kilograms } & \multicolumn{1}{c|}{ Groups } \\
\hline $59 \mathrm{KG}, 66 \mathrm{KG}, 71 \mathrm{KG}$ & Lightweight \\
\hline $75 \mathrm{KG}, 80 \mathrm{KG}, 85 \mathrm{KG}$ & Middleweight \\
\hline $98 \mathrm{KG}, 130 \mathrm{KG}$ & Heavyweight \\
\hline
\end{tabular}

There was a significant difference between the technical and score points according to weight groups. Numbers of technical points for one competition between Weight Groups demonstrated differences $(p<.001)$. Technics of Lightweight and Middleweight groups was higher than that in Heavyweight group. Ratio of received points for one competition between Weight Groups was different $(p<.05)$. Points of Lightweight group are higher than that in Middleweight group (Table 2).

Table 2. Distribution of technical and match numbers scored by each weight group

\begin{tabular}{|c|c|c|c|c|c|}
\hline Weight Groups & $\begin{array}{l}\text { Number of } \\
\text { technical points }\end{array}$ & $\begin{array}{l}\text { Number of } \\
\text { points scored }\end{array}$ & $\begin{array}{l}\text { Number of } \\
\text { matches by } \\
\text { groups }\end{array}$ & $\begin{array}{l}\text { Number of technical } \\
\text { points for one } \\
\text { competition }\end{array}$ & $\begin{array}{l}\text { Ratio of received } \\
\text { points for one } \\
\text { competition }\end{array}$ \\
\hline Lightweight (1) & 157 & 245 & 36 & 4.36 & 6.81 \\
\hline Middleweight (2) & 121 & 174 & 30 & 4.03 & 5.80 \\
\hline Heavyweight (3) & 63 & 116 & 19 & 3.11 & 6.11 \\
\hline Total & 341 & 535 & 85 & 4.01 & 6.29 \\
\hline F/LSD & & & & $\begin{array}{l}10.55 * * \\
3<1.2\end{array}$ & $\begin{array}{l}4.25^{*} \\
1>2\end{array}$ \\
\hline
\end{tabular}


In Figure 1, the technique with the highest score was the passive punishment points obtained by reducing the competitor to passive status at a rate of $28 \%$. After all that with the order of the most point taken from $16 \%$ point from snap down technique and spin behind technique, $14 \%$ of the point taken from move out of the mat techniques.

In Figure 2, 79\% lightweight wrestlers won by score, while $21 \%$ won by technical superiority. In these weight groups there were no winner by pin.

In Figure 3, the middleweight wrestlers had the highest score of $38 \%$ with a passive punishment point. Later on, the techniques were made with $16.5 \%$ high dive and takedown, $12 \%$ move out of the mat point techniques.
In Figure 4, 81\% middleweight wrestlers won by score, while $15.5 \%$ won by the technical superiority and $3 \%$ won by the pin.

In Figure 5, the heavyweight wrestlers got the most points from $33 \%$ of the passive punishment point. After that orderly $22 \%$ each point got from move out of the mat and high dive takedown techniques made it.

In Figure 6, 83\% heavyweight wrestlers won by the score, while $11 \%$ won by the pin and $5.5 \%$ won by the technical superiority.

In Figure 7, a total of 85 matches made in tournament, $56 \%$ of the objections made by the coaches to the arbitration committee were rejected while $44 \%$ were accepted.

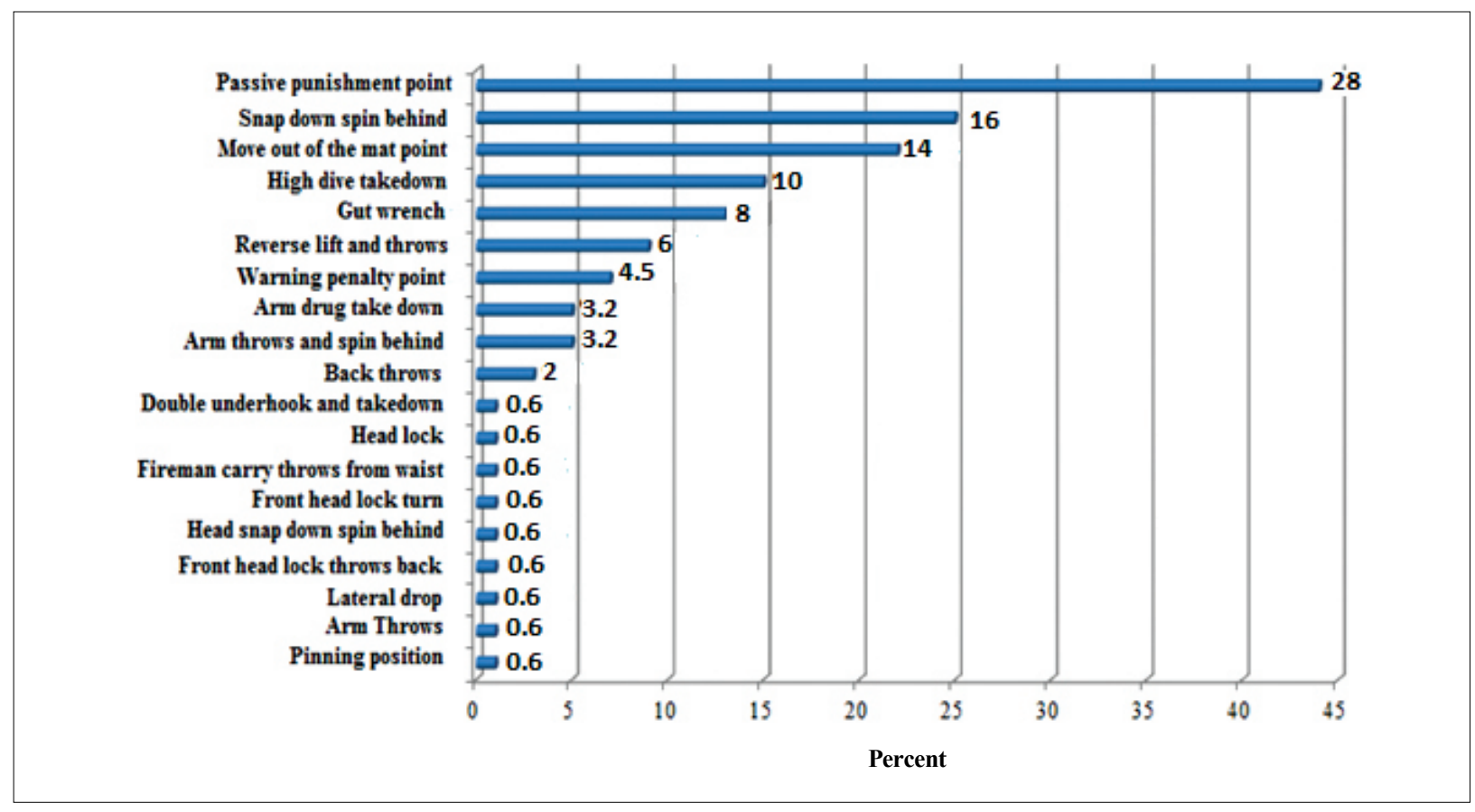

Figure 1. The percentage distribution of successful techniques made by lightweight wrestlers

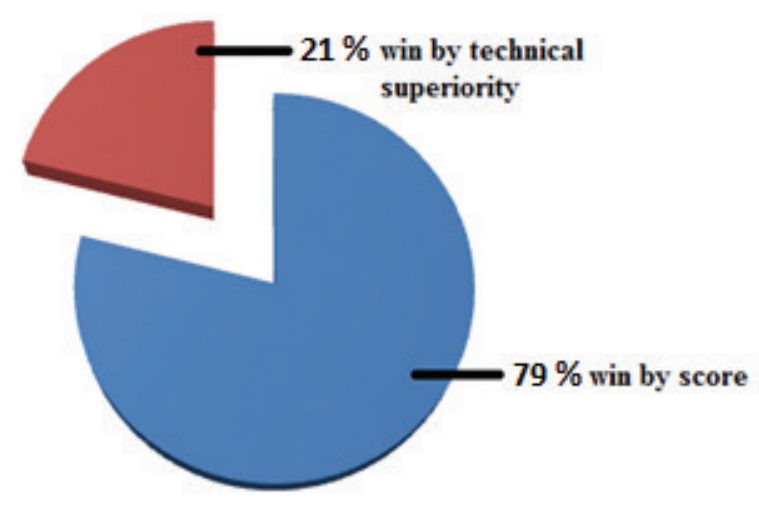

Figure 2. The percentage distribution of lightweight wrestlers' winning types 


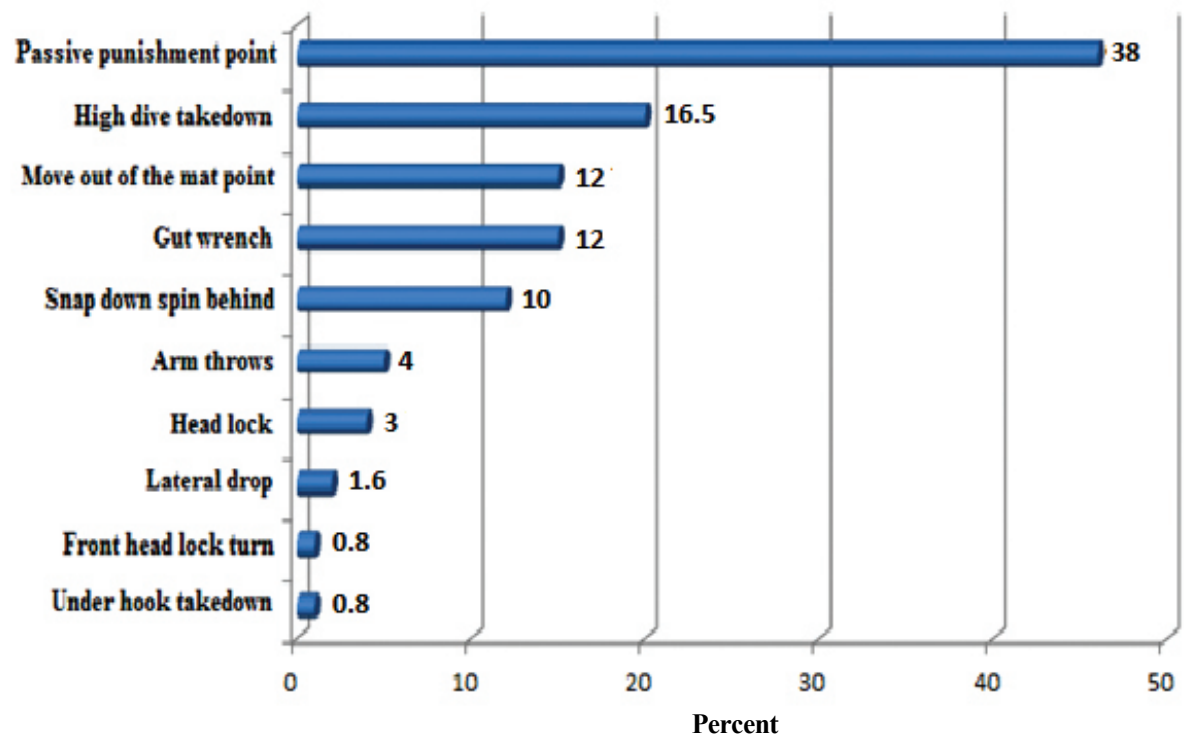

Figure 3. The percentage distribution of successful techniques made by middleweight wrestlers

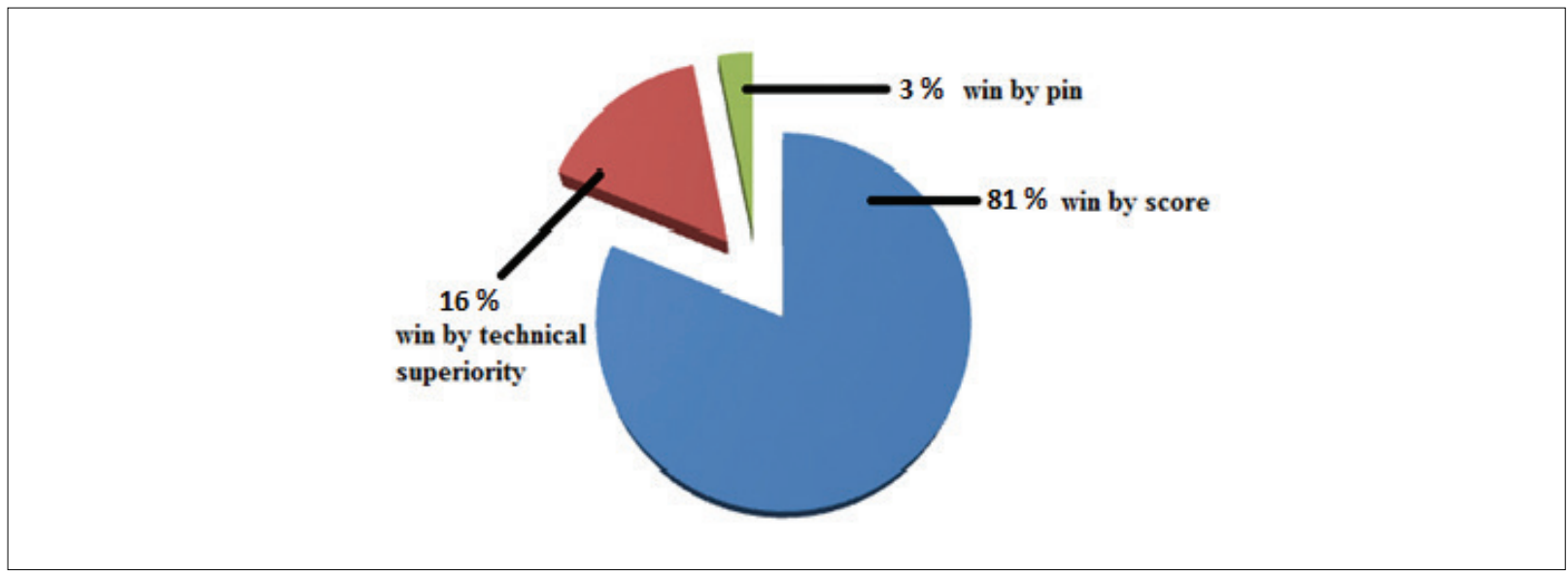

Figure 4. The percentage distribution of middleweight wrestlers' winning types

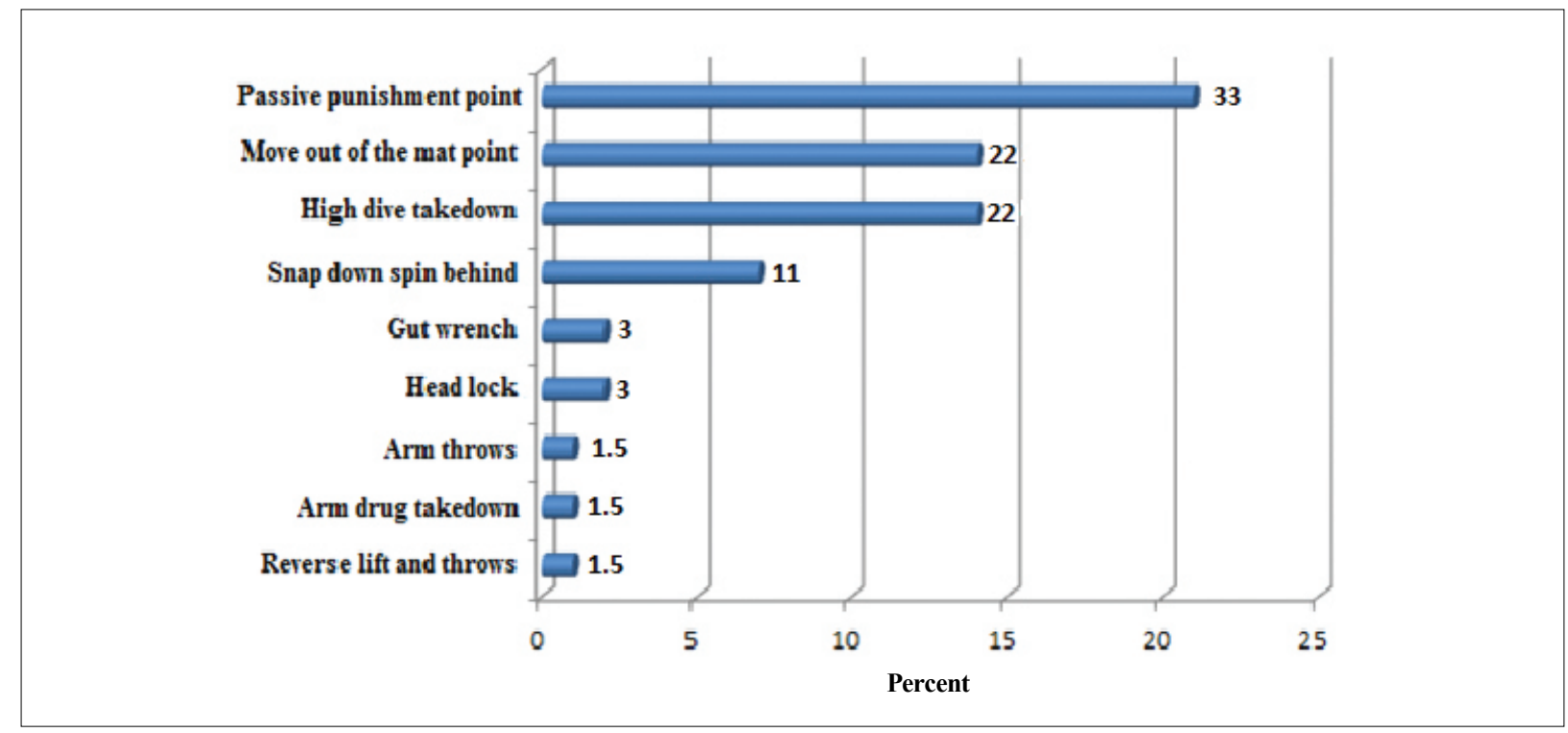

Figure 5. The percentage distribution of successful technique made by heavyweight wrestlers' 
Figure 6. The percentage distribution of heavyweight wrestlers' winning types
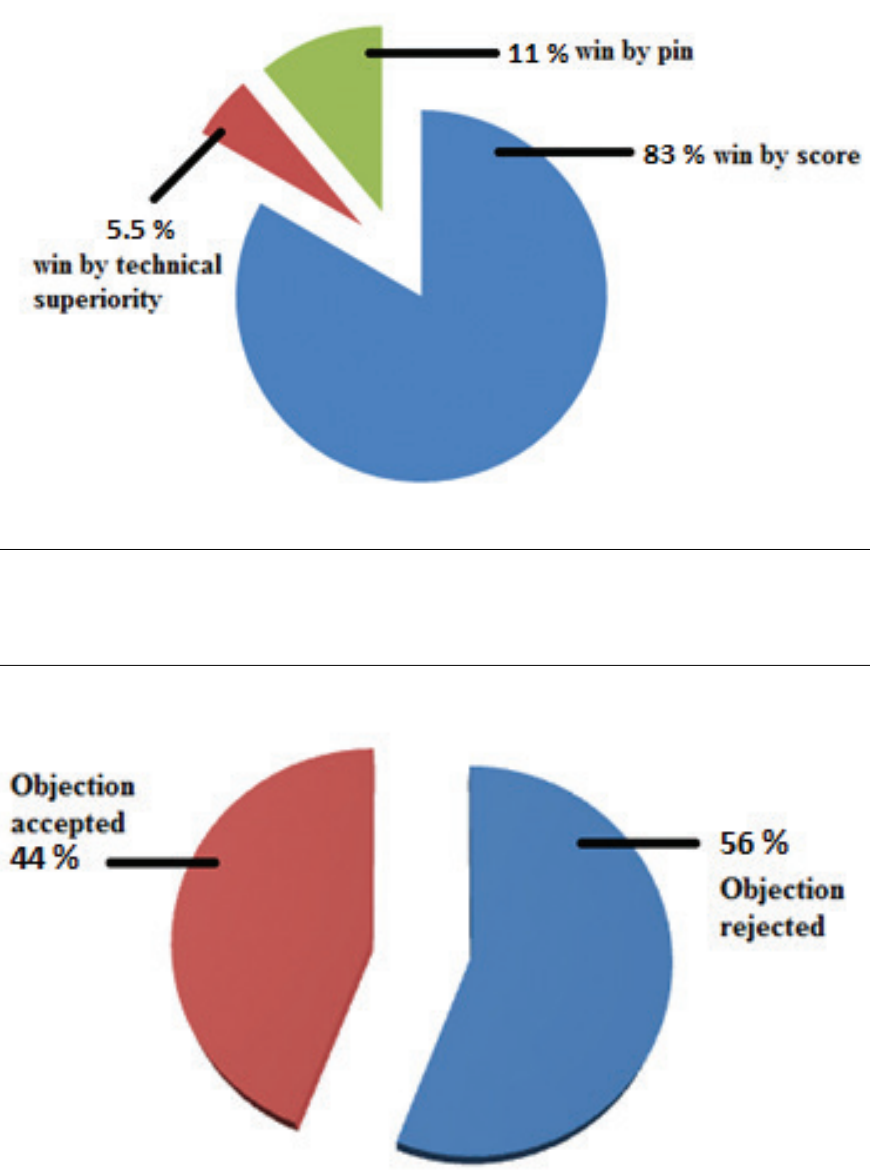

Table 3. International Senior 12th World Universities Wrestling Championship GR Style ranking

\begin{tabular}{|c|c|c|c|c|c|c|c|c|c|c|}
\hline Rang & Equipe & $130 \mathrm{KG}$ & $59 K G$ & $66 \mathrm{KG}$ & $71 K G$ & $75 K G$ & $80 K G$ & $85 K G$ & $98 K G$ & TOTAL \\
\hline 1 & TUR & 6 & 8 & 10 & 8 & 8 & 9 & 7 & 10 & 66 \\
\hline 2 & BLR & 9 & & 9 & 10 & 6 & 8 & 9 & 8 & 59 \\
\hline 3 & IRI & 8 & 9 & 8 & 8 & 8 & 6 & 6 & 6 & 59 \\
\hline 4 & RUS & 8 & 6 & 1 & 6 & 2 & 8 & 8 & 8 & 47 \\
\hline 5 & HUN & 10 & 3 & 3 & 3 & & 10 & 10 & 6 & 45 \\
\hline 6 & $\mathrm{POL}$ & 6 & 4 & 6 & 2 & 9 & 3 & & & 30 \\
\hline 7 & KGZ & & 10 & & & 10 & 4 & & 3 & 27 \\
\hline 8 & KAZ & 4 & 6 & & 9 & & & & & 19 \\
\hline 9 & MDA & & 8 & 4 & & 4 & & & 2 & 18 \\
\hline 10 & GER & 4 & & & 4 & & 6 & & 4 & 18 \\
\hline 11 & GEO & & 2 & 8 & & 6 & & & & 16 \\
\hline 12 & AUT & & & & & & & & 9 & 9 \\
\hline 13 & UKR & & & 2 & 6 & & & & & 8 \\
\hline 14 & FRA & & & 6 & & & & & & 6 \\
\hline 15 & GRE & & & & & 3 & & & & 3 \\
\hline 16 & ESP & & & & & & 2 & & & 2 \\
\hline 17 & EST & & & & & & & & & 0 \\
\hline 17 & ROU & & & & & & & & & 0 \\
\hline
\end{tabular}

Reference: Turkish University Sport Federation (2016). 


\section{DISCUSSION}

In this study, a significant difference was found between the technical and score points according to weight groups. The technics of Lightweight and Middleweight groups was higher than in Heavyweight group $(p<.001)$. Points of Lightweight group were higher than those in Middleweight group $(p<.05)$.

Imamoglu et al. (2004) analysed two European Junior Freestyle and Greco-Roman Wrestling Championships, and most of the Greco-Roman and the Free-Style competitions finished in official time and by points. In the free-style wrestling, the total of 1278 techniques (Ratio for One Competition: ROC: 5.58) were applied and 1951 points (ROC: 8.51) were taken: for one competition 0.32 passivity and 0.17 tying salto was performed. In the GrecoRoman wrestling, 1262 techniques (ROC: 4.53) were applied and 2114 points (ROC: 7.60) were taken: for one competition 0.33 passivity and 1.22 tying salto was performed.

Turkmen, Imamoglu, \& Demirhan (2013) found that in 2013 Universiade Games in men's GrecoRoman and Freestyle wrestling, the numbers and victory were as $45.5 \%$ and technical victory was as $42.5 \%$ with 7 points difference. The point scored in the first circuit (round) of each match in freestyle was (Ratio for One Competition: ROC: 6.14), while in Greco-Roman style it was (ROC: 5.26). The points obtained in the second round of each match in freestyle were as 2.78, while in Greco-Roman style it was (ROC: 3.12 ). The total points obtained by the victors in Freestyle for each match was (ROC: 7.44 ) and the points obtained by the losers are (ROC: 1.89).

Kolukisa et al. (2004b) recorded 49 European Greco-Roman Wrestling Championships, and most of the Greco-Roman competitions finished in official time and by points in all weight categories. The most used techniques were found as respectively gut wrench, tying salto and warning point. In the Greco-Roman wrestling, there were taken a total of 1585 points, therefore the mean of total points was (Ratio for One Competition: ROC: 7.23).

Atan and Imamoglu (2005) recorded data from 46 World Greco-Roman Wrestling Championships and 35 World Free-Style Championships where most executed techniques were gut wrench (29.62\%), tying salto $(14.81 \%)$ and counter to gut wrench $(9.25 \%)$ in the classifying Greco-Roman; leg tackle $(36.36 \%)$, gut wrench $(16.66 \%)$ and head drug (12.12\%) in the classifying free-style wrestling. In this study, the Greco roman wrestling total 341 techniques (Ratio for One Competition: ROC: 4.01) were applied with1951 points (ROC: 6.29).

Soyguden et al. (2015) reported that Turkish U-23 Greco-Roman wrestler techniques with the highest score taken on the Greco-Roman style were arm throws, head lock, move out of the mat, high dive and take down, snap down spin behind, throws, front throws and gut wrench techniques.

Soyguden, Toy, Hos, and Mumcu (2015) found that in Turkish U-23 Greco-Roman wrestler and this study Greco-Roman wrestling most technique performed $83 \%$ on the standing position and $17 \%$ technique on the ground position. At the 2011 World Senior Wrestling Championship in GrecoRoman style most technique performed $71 \%$ on the ground position and $29 \%$ technique performed on the standing position (Dokmanac, Karadzic, \& Doder, 2012).

Mirzaei and Akbar (2008) found in their study with the elite Iranian Greco-Roman wrestlers, the Greco-Roman wrestlers scored the most points from the techniques of head lock, arm throws, under hook takedown, arm drug and gut wrench. Our study showed similar results but we found only the techniques of passive punishment point used by wrestler because of the Greco-Roman wrestling rules.

The review of Greco-Roman wrestlers' performances at Olympic Games 2008 and Olympic Games 2012 permits to make a conclusion that no matter how the level of technical preparedness is, how efficient technique is used by a wrestler, it is impossible to apply any technique without appropriate tactical preparedness. The rule changes our work often affect the technical and tactical work of the wrestlers (Tropin, 2013).

Atan and Imamoglu (2005) analysed data from 46 World Greco-Roman and in 35 World FreeStyle Championships, most of the Greco-Roman and the Free-Style competitions finished in official time and by points in all weight categories.

In the head drug position more effective techniques have to be applied. According to the position, advantages and disadvantages of the techniques have to be taught to the wrestlers. The trainers can regulate the wrestlers' training 
programs by considering the techniques used by the general, and also semi-finalist and champion wrestlers in the championships (Atan and Imamoglu, 2005).

It is connected with constantly growing competitiveness on the base of science and technical achievements' introduction into training process and with perfection of sportsmen's training methods (Hughes and Bartlett, 2002; Malkov, 2006).

It has been argued that some of the rule changes made to make wrestling more active may or may not bring benefits to the wrestling sport. Changes made on the Greco-Roman style are not welcomed by wrestlers. In this study, it seems that the result of the rule changes made the differentiation of the score techniques. It is connected with constantly increasing competition on the basis of introduction of achievements of science and technique in the training process and improvement of technique of training of sportsmen (Iermakov, Podrigalo, Romanenko, Tropin, \& Boychenko, 2016; Tropin et al., 2016; Shatskikh, 2013; Bromber, Krawietz, \& Petrov, 2014).

\section{CONCLUSION}

As a result, the most effective technique in Greco-Roman style given by the referee was passive punishment point in all weight groups. In this case, the wrestlers need to be more active in the bilateral struggle. In particular, it is suggested to fight tempo wrestling with their arms and chest by fighting against each other and struggle in the standing position.

We can see that study showed that most points were taken from the standing position and passive punishment points. Some changes in the rules of wrestling cause changes in the technical and tactical work of the wrestlers. Especially the changes made in the Greco-Roman style have had negative effects on the wrestlers. In the study we have done, this rule is seen from the points taken as the result of the changes.

Our result showed that passive punishment point was very effective in the Greco-Roman wrestling and we recommend to wrestling coaches that they should train wrestlers' passivity actions.

\section{REFERENCES}

Atan, T., \& İmamoğlu, O. (2005). Competition analysis of World Greco-Roman and World free-style wrestling championships. International Journal of Performance Analysis in Sport, 5(1), 31-40.

Bromber, K., Krawietz, B. \& Petrov, P. (2014). Wrestling in multifarious modernity. The International Journal of the History of Sport, 31(4), 391-404. doi:10.1080/0952 3367.2013.869217.

Dokmanac, M., Karadzic, P. \& Doder, D. (2011). Statistical analysis of the Wrestling World Champıonships: Istanbul-2011. International Journal of Wrestling Science, 2(1), 53-66.

Hughes, M. D., \& Bartlett, R. M. (2002). The use of performance indicators in performance analysis. Journal of Sports Sciences, 20(10), 739-754.

Iermakov, S., Podrigalo, L., Romanenko, V., Tropin, Y. \& Boychenko, N. (2016). Psycho-physiological features of sportsmen in impact and throwing martial arts. Journal of Physical Education and Sport, 16(2), 433-441.

Imamoglu, O., Atan, T., Kolukısa, S., Kaldırımcı, M., \& Kishali, N. F. (2004). Yıldızlar Avrupa Serbest ve Grekoromen Güreş Şampiyonası Müsabaka Analizi, Atatürk Üniversitesi Beden Eğitimi ve Spor Bilimleri Dergisi, Erzurum, Cilt 4, Sayı 4, Sh. 29-37.

Kolukısa, S., Imamoglu, O., Ziyagil, M. A., \& Kishali, N. F. (2004a). 46. Dünya Grekoromen ve 35. Dünya Serbest Güreş Şampiyonası Müsabaka Teknik
Analizi Karşılaştırması, Atatürk Üniversitesi Beden Eğitimi ve Spor Bilimleri Dergisi, Erzurum, Cilt 6, Say1 1, Sh.18-29.

Kolukisa, S., Ziyagil, M. A., Imamoglu, O., Kishali, N. F. (2004b). Competition Technique Analysis of 49. European Greco-Roman Wrestling Championship, Atatürk Üniversitesi BESYO, Beden Eğitimi ve Spor Bilimleri Dergisi, Cilt : 6, Sayı: 3, s.1-7.

Malkov, O. B. (2006). Teoreticheskie aspekty tekhniki $i$ taktiki sportivnoj bor'by. Moscow: Physical Culture and Sport.

Mirvic, E., Kazazovic, B., \& Aleksandrovic, M. (2011). Differences between winning and losing teams from World water polo Championship for women. Homo Sprorticus, 2(13), 41.

Mirzaei, B., \& Akbar, N. (2008). Skill profile of elite Iranian Greco-Roman Wrestlers. World Journal of Sport Sciences, 1, 8-11.

Mizerski, M. (1972). O celowości prowadzenia obserwacji walki sportowej. Sport Wyczynowy, 5.

Hitit University. (2016). Retrieved from http://www.hitit. edu.tr/haberler/2016/10/26/12-dunya-universiteler-guressampiyonasi-gorkemli-bir-acilisla-basladi (26 Oct.2016).

Ortega, E., Cardenas, D., Sainz De Baranda, P., \& Palao, J. M. (2006). Differences between winning and losing teams in youth basketball games (14-16 years old). International Journal of Applied Sports Science, 18(2), 1-11. 
Ryan, T., \& Sampson, J. (2006). Elite wrestling. New York: McGraw-Hill.

Sandberg, E., \& Bell, N. T. (2007). Coaching Youth Wrestling. Human Kinetics, Illinois.

Shatskikh, V.V.(2013). Dynamics of psychophysiological state wrestlers Greco-Roman style in the current control. Visnik Prikarpatskogo universitetu. Fizichna kultura, 17, 205-209.

Soyguden, A., Toy, A. B., Hos, S., \& Mumcu, Ö. (2015). The Technical Analyses of Turkey U-23 GrecoRoman and Free Style Wrestling Championships. ASOSJOURNAL (The Journal of Academic Social Science), 3(12), 213-224.

Tropin, Y., Romanenko, V. \& Ponomaryov, V. (2016). Model characteristics of sensory-motor reactions and perceptions of specific wrestlers of different styles of confrontation, Slobozhanskyi Herald of Science and Sport, 3, 205-209.

Tropin, Y. M. (2013). Comparative analysis of technical and tactical preparedness Greco-Roman style wrestler at the Olympic Games-2008 and the Olympic Games-2012. Physical Education of Students, 4, 92-96.

Turkish University Sports Federation. (2016). Retrieved from http:/www.tusf.org/Data/Sites/1/corum2016/final books/wucwrestling_final_results_teap.pdf(E.T.22/2/2017)

Turkmen, M., Imamoglu, O., \& Demirhan, B. (2013). 2013 Universiade match analysis from the perspective of wrestling's new rules. International Journal of Wrestling Science, 3(2), 105.

Turkmen, M., Imamoglu, O., \& Ziyagil, M. A. (2004). Competition Analysis of 46 World Greco-Roman Wrestling Championship. In The 10 Ichber sd. Europa Congress- The Tssa 8 International Sports Science Congress, abstract book, S077. Antalya-Turkey.

United world wrestling. (2017). Retrieved from https:// unitedworldwrestling.org/sites/default/files/media/ document/wrestling_rules_a_0.pdf

Vardar, S. A., Tezel, S., \& Ozturk, L. (2007). The relationship between body composition and anaerobic performance of elite young wrestlers. Journal of Sports Science and Medicine, 6, 34-38. 